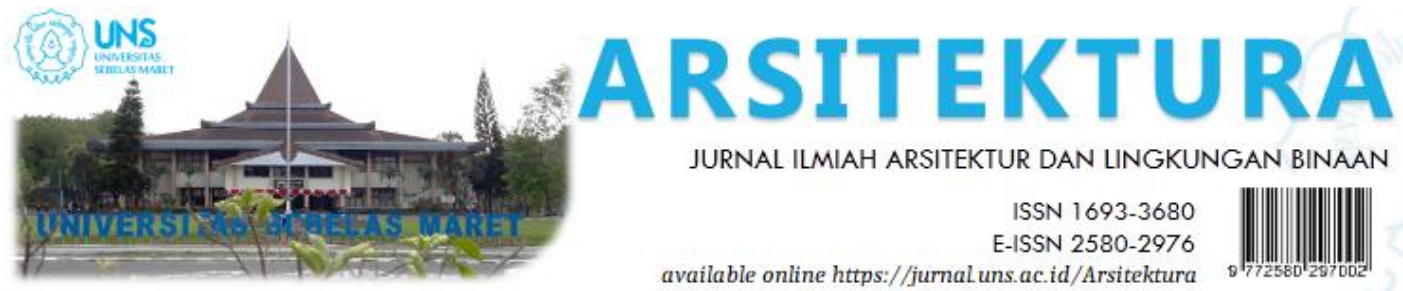

Volume 18 Issue 2 October 2020, pages:199-214

\title{
Retrofit pada Bangunan Komersial Tinjauan Masalah dan Metode
}

\author{
Retrofit in Commercial Buildings \\ A Review of Problems and Method
}

\author{
Annisa Fikriyah Tasya ${ }^{1 *}$, Purwanita Setijanti ${ }^{2}$, Asri Dinapradipta ${ }^{3}$ \\ Departemen Arsitektur, FTSPK Institut Teknologi Sepuluh Nopember" \\ annisa.fikriyah_tasya@yahoo.com \\ Departemen Arsitektur, FTSPK Institut Teknologi Sepuluh Nopember ${ }^{2}$ \\ Department Arsitektur, FTSPK Institut Teknologi Sepuluh Nopember ${ }^{3}$
}

DOI: https://doi.org/10.20961/arst.v18i2.42632

Received: July 4, 2020 Revised: July 21,2020 Accepted: July 23, 2020 Available online: October 31, 2020

\begin{abstract}
At present energy efficiency is the main target to reduce building operating costs and achieve sustainability. The use of energyin buildings can be done through retrofitting. In addition, retrofitting has the potential to reduce carbon emissions, but there are also those who have to release some building features if necessary, energy features that are applied to existing buildings that have been issued to carry out renovations. Building reinforcement is a complex act, with various criteria that must be met with each other to achieve sustainable use of buildings. This article discusses the benefits, criteria, analytic methods, and decision making processes used to improve commercialbuildings. The main criteriafor increased energy consumption. Some other criteria are building materials, economy and occupants'needs. The analytical method for estimating or measuring the increase in retrofit that will be discussed in thisarticle is a simulation of building energy. This method is widely used because it can predict the condition of buildings in the future. Each retrofitstep is chosen and approved by the several factors; regulations, risks, business sustainability, knowledge, awareness and occupant demand. The retrofit valuation process is based on the value at which financial performance is taken into account. Retrofitting carried out on commercial buildings, applied with care, not only provides opportunities to reduce energy consumption and carbon emissions, but can also increase the value of these properties.
\end{abstract}

Keywords: energyefficiency, existing buildings, guidelines, retrofit, sustainable

\section{PENDAHULUAN}

Saat ini konsumsi energi menjadi topik yang sangat penting di seluruh dunia, menurut World Energy Council, permintaan energi secara global diperkirakan akan naik dua kali lipat pada tahun 2050, secara bersamaan emisi gas rumah kaca harus dikurangi untuk menjaga kenaikan suhu global di bawah dua derajat Kelvin (Mendes and Mendes, 2019). Bangunan 
menghasilkan $50 \%$ total pengeluaran energi di Indonesia dan lebih dari $70 \%$ konsumsi listrik keseluruhan, serta bertanggung jawab bagi $30 \%$ emisi gas rumah kaca dan bahan baku yang diproduksi (Gunawan, 2012). Selain konstruksi baru (new building), terdapat peluang untuk meningkatkan efisiensi bangunan yang ada yakni dengan melakukan retrofit pada bangunan existing. Menurut Dunphy dkk (2013) yang dikutip dari Morrissey dkk (2014), retrofit bangunan penting dan semakin berkembang dibidang konstruksi. Kneifel (2010), mengatakan bahwa hal ini menjadi penting dan peluang dalam pengurangan energi dan emisi yang berkaitan dengan biaya serta implementasi. Retrofit bangunan memiliki banyak tantangan dan peluang. Tantangan utama yang dihadapi adalah adanya ketidakpastian (uncertainties), seperti perubahan iklim, perubahan layanan, perubahan perilaku manusia, dan perubahan kebijakan pemerintah (Ma et al., 2012).

Pengembangan bangunan mixed use (bangunan multifungsi) dipahami sebagai hal penting untuk mencapai "compact city" dan lingkungan perkotaan yang layak dalam bidang perencanaan perkotaan. Permukaan yang kedap air dan tingginya kepadatan pengembangan bangunan menyebabkan terjadinya fenomena urban heat island (UHI), karena bangunan diidentifikasi mengalami peningkatan konsumsi listrik (Woo and Cho, 2018). Sebagian besar studi tentang UHI telah meneliti hubungan antara lingkungan yang dibangun dan karakteristik iklim pada skala kota, tetapi hasil penelitian Young-Eun Woo dan Gi-Hyoug Cho, 2018 menyiratkan bahwa lingkungan terdekat dari suatu bangunan dapat mempengaruhi iklim mikro-kota. Penyediaan ruang hijau di sekitar bangunan akan mengurangi UHI dan sudut obstruksi fasad bangunan, sehingga membantu mengurangi konsumsi energi listrik dan gas. Penelitian Young-Eun Woo dan Gi-Hyoug Cho, 2018 menunjukkan bahwa proporsi penggunaan energi pada bangunan mixed use lebih tinggi dari penggunaan non-perumahan. Kota yang memiliki tingkatan pembangunan komersial yang tinggi, cenderung mengalami peningkatan konsumsi listrik di daerah tersebut secara signifikan (Woo and Cho, 2018). Pemahaman mengenai hubungan antara pengaturan tata ruang bangunan mixed used dengan kebutuhan listriknya akan membantu perencana kota dan pembuat kebijakan untuk menyediakan infrastruktur energi perkotaan yang efisien serta berdampak pada peningkatan efisiensi energi.

Indonesia sebagai salah satu negara yang telah berkomitmen untuk mengurangi emisi rumah kaca sebesar 26\% ditahun 2020. Terdapat 140 bangunan yang telah menerima sertifikasi bangunan GREENSHIP (per Oktober 2015). Pemerintah telah mengeluarkan undangundang yang berkaitan dengan peningkatan kualitas lingkungan bangunan (International Finance Corporation, 2017).

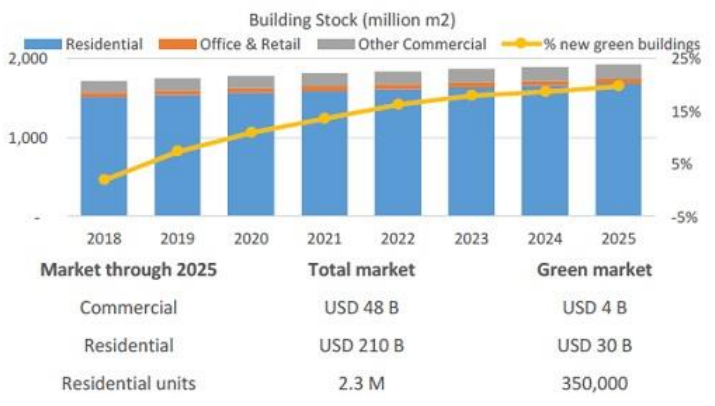

Gambar 1. Pertumbuhan Stok Bangunan di Indonesia

Sumber: Na vigant Research GlobalBuilding Stock Da tabase, 2017

Gambar 1 menjelaskan mengenai tren pertumbuhan jumlah bangunan yang ada (building stock) di Indonesia. Melihat gambar tersebut diperkirakan jumlah building stock akan mengalami peningkatan setiap tahunnya. Sektor konstruksi telah menyumbang sekitar 10\% dari GDP (Gross Domestic Product) (per Mei 2016). Selain itu terdapat beberapa lembaga non profit yang berkaitan dengan bangunan keberlanjutan di Indonesia. Salah satunya adalah GBCI (Green Building Council Indonesia) yang merupakan anggota baru dari WGBC (World Green Building Council). IFC (International Finance Corporation) yang bermitra dengan GBCI pada tahun 2015 telah meluncurkan program sertifikasi bangunan bernama EDGE (International Finance Corporation, 2017). Semua ini merupakan bentuk pemerintah dalam mendukung keberlanjutan. Indonesia mengalami pertumbuhan yang sehat di semua sub-sektor properti. Bangunan komersial tumbuh lebih cepat dibandingkan dengan residensial, tetapi 
stok residensial masih menjadi bagian terbesar dari bangunan yang ada. Hal ini terjadi karena tingginya kebutuhan perumahan di Indonesia akibat dari pertumbuhan populasi yang terus meningkat. Konsep bangunan hijau menjadi solusi keberlanjutan di sektor properti. Dimana tantangan terbesar adalah tingginya jumlah bangunan yang sudah berdiri (building stock) yang belum mengimplementasikan konsep hijau.

Bangunan hijau diperkirakan dapat mencapai sebasar $20-25 \%$ di pasar properti pada tahun 2025 karena kombinasi dari dukungan kebijakan, manfaat pajak, program pendidikan dan kesadaran, dan penghematan yang akan direalisasikan dari efisiensi energi (Gambar 2). IFC memproyeksikan bahwa persentase keseluruhan bangunan hijau baru diperkirakan akan meningkat $2 \%$ hingga $5 \%$ setiap tahun, setidaknya sampai 2030 (International Finance Corporation, 2017).

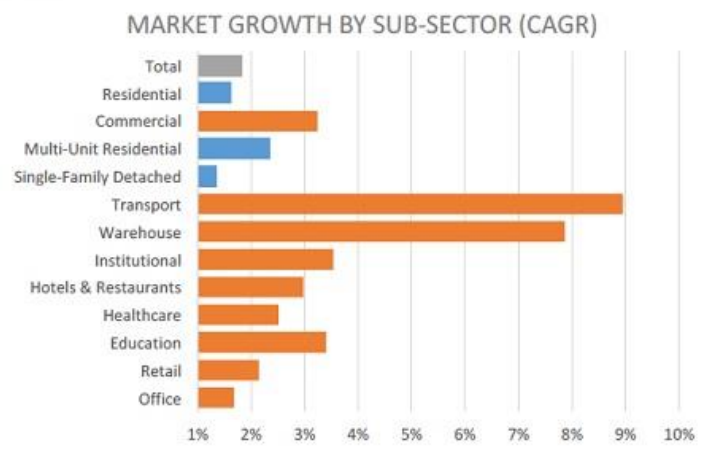

Gambar 2. Pertumbuhan Pasar Properti Indonesia Sumber: Na viga nt Research Global Building Stock Database, 2017.

Di antara semua jenis bangunan, blok komersial menyumbang bagian tertinggi dalam konsumsi energi bangunan non-perumahan (Hong, Deng and Ezeh, 2019). Oleh karena itu, direkomendasikan bahwa gedung komersial harus diprioritaskan untuk melakukan retrofit karena akan berkontribusi secara signifikan terhadap lingkungan hijau yang berkelanjutan. Namun retrofit yang diterapkan pada bangunan eksisting mungkin memiliki peluang ketidak sesuaian dan dapat menyebabkan kerusakan pada bangunan. Sehingga diperlukan pembahasan mendalam mengenai kriteria, metode analisis, serta proses pengambilan keputusan yang digunakan untuk melakukan retrofit pada bangunan komersial. Salah satu masalah mendasar dari retrofit pada real estat adalah mengukur berbagai aspek baik dari segi risiko, ekonomi, dan kebutuhan pengguna. Hal ini mendorong pertanyaan mengenai kemampuan bangunan komersial dapat melakukan retrofit bangunan dengan tetap mempertimbangkan aspek lingkungan dan ekonomi. Ulasan ini dimaksudkan untuk membantu menentukan strategi retrofit bangunan komersial dengan memperhatikan kriteria retrofit dan metode yang akan digunakan. Artikel ini akan meninjau manfaat, kriteria retrofit, metode penilaian yang digunakan untuk memperkirakan atau mengukur kinerja retrofit serta panduan tentang proses pengambilan keputusan dalam memilih opsi retrofit.

\section{METODE}

Penelitian ini dilakukan dengan metode literature review dengan penyajian data kualitatif secara naratif. Narative review dipilih untuk melakukan tinjauan berkaitan dengan retrofit bangunan. Menurut Snyder (2019) terdapat beberapa langkah dasar untuk melakukan tinjauan pustaka yakni; (1) merancang ulasan, (2) melakukan tinjauan, (3) analisis dan (4) menulis ulasan. Tahap pertama yang dilakukan adalah merancang ulasan dengan merumuskan tujuan, ruang lingkup, dan pertanyaan penelitian secara spesifik yang akan dibahas oleh ulasan. Setelah pertanyaan penelitian telah diidentifikasi, strategi pencarian untuk mengidentifikasi literatur yang relevan harus dikembangkan. Termasuk dalam memilih istilah pencarian dan database yang sesuai. Pada penelitian ini kata kunci utama yang digunakan adalah building retrofit. Tahap kedua adalah melakukan tinjauan yang dilakukan setelah memutuskan tujuan, pertanyaan penelitian spesifik, dan jenis pendekatan. Artikel yang dipilih harus dipastikan kualitas dan kesesuaian topik. Untuk mengulas setiap artikel yang didapat dibantu dengan teknik membaca skimming. Tinjauan dilakukan dengan membaca abstrak terlebih dahulu kemudian membaca artikel teks secara lengkap kemudian, sebelum membuat pilihan akhir. Sebagai strategi tambahan, referensi dalam artikel yang dipilih dapat dipindai untuk mengidentifikasi artikel lain yang mungkin relevan. 
Setelah melakukan tinjauan pustaka dan memutuskan sampel akhir, tahap berikutnya adalah melakukan analisis dengan mencari inti sari dari setiap sumber artikel yang digunakan. Data yang diringkas dapat berupa informasi deskriptif, seperti penulis, tahun yang diterbitkan, topik, atau jenis studi, atau dalam bentuk efek dan temuan. Selain itu dapat mengambil bentuk konseptualisasi ide atau perspektif teoritis tertentu. Hal terpenting, semua ini harus dilakukan sesuai dengan tujuan dan pertanyaan penelitian. Tahapan terakhir adalah melakukan penulisan. Pertama, ketika menulis, motivasi dan kebutuhan tinjauan literatur harus dikomunikasikan dengan jelas. Kontribusi tinjauan literatur secara spesifik harus dinilai keterkaitannya dengan bidang yang ingin dikontribusikan (Snyder, 2019).

\section{HASIL DAN PEMBAHASAN}

\subsection{Kriteria Retrofit Bangunan}

Retrofit merupakan penyeimbang antara konsumsi energi dan prinsip konservasi yang dilakukan untuk mencapai penggunaan bangunan yang berkelanjutan dalam jangka panjang. Pada dasarnya, inovasi dalam retrofit adalah tentang perubahan yang menghasilkan peningkatan dengan tujuan pengurangan emisi karbon. Inovasi merupakan konsep sosio-teknis dimana konteks organisasi, regulasi dan berbagai pemangku kepentingan (stakeholder) bergabung untuk mendorong terwujudnya suatu inovasi. Terdapat beberapa faktor yang perlu dipertimbangkan ketika berinovasi dalam rezim energi domestik. Geels (2005) dalam buku Swan and Brown (2013) mengidentifikasi tiga tingkat yang berinteraksi ketika mempertimbangkan inovasi dalam konteks sosial-teknis, seperti yang ditunjukkan pada Gambar 3.

Pada tingkatan pertama berkaitan dengan lanskap bangunan, yang mencakup faktorfaktor di luar sistem yang memiliki pengaruh penggerak. Dalam hal inovasi retrofit, faktor tersebut berkaitan dengan perubahan iklim atau penurunan cadangan energi. Lapisan kedua adalah rezim sosio-teknis, hal ini berkaitan dengan struktur artefak (bangunan), aktor dan aturan yang menghubungkan dalam pembentukan sistem. Lapisan terakhir adalah detail inovasi. Inovasi ini dikembangkan di tingkat mikro dan kemudian harus diadopsi ke dalam rezim jika ingin digunakan secara luas. Rezim dapat menyesuaikan inovasi baru, karena cocok dalam rezim yang ada, atau rezim dapat beradaptasi untuk mengakomodasi inovasi baru. Atau, inovasi mungkin ditolak oleh rezim dan gagal total. Pandangan ini terkait erat dengan konsep gangguan dari teori inovasi (Henderson dan Clark 1990). Kriteria retrofit dapat dikelompokkan ke dalam empat kategori: lingkungan, teknikal, sosial, dan ekonomi (Si and Marjanovic-Halburd, 2018). Tabel 1 mencantumkan empat kategori kriteria untuk menilai dampak retrofit, dimana setiap kriteria saling dikaitkan.

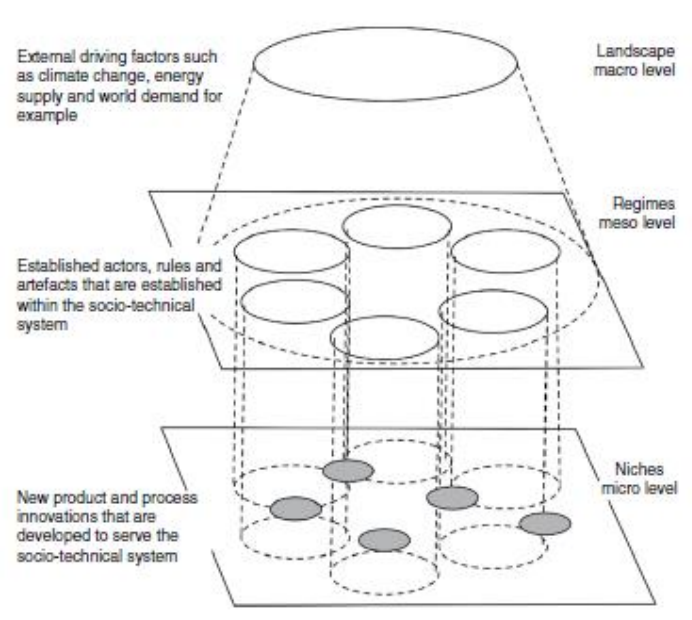

Gambar 3. Tiga tingkatan sistem sosial-teknis yang dia daptasi teori Geels 2005 Sumber: Swan and Brown, 2013

Tabel 1. Kriteria yang Digunakan untuk Menilai Dampak Retrofit Energi

\begin{tabular}{|c|c|c|}
\hline Kategori & Kriteria & Parameter \\
\hline \multirow[t]{2}{*}{ Lingkungan } & $\begin{array}{l}\text { Kinerja } \\
\text { Lingkungan }\end{array}$ & $\begin{array}{l}\text { Pengurangan emisi } \\
\text { gas } \mathrm{CO}_{2} \text {. } \\
\text { Pengurangan } \\
\text { konsumsi energi. } \\
\text { Pengurangan } \\
\text { konsumsi air. } \\
\text { Peningkatan kualitas } \\
\text { lingkungan dalam } \\
\text { ruangan. }\end{array}$ \\
\hline & $\begin{array}{l}\text { Konten Daur } \\
\text { Ulang }\end{array}$ & $\begin{array}{l}\text { Peningkatan } \\
\text { pengelolaan sampah. }\end{array}$ \\
\hline Sosial & Penghuni & $\begin{array}{l}\text { Kenyamanan termal } \\
\text { Kualitas udara dalam } \\
\text { ruangan }\end{array}$ \\
\hline
\end{tabular}




\begin{tabular}{ccl}
\hline Kategori & Kriteria & \multicolumn{1}{c}{ Parameter } \\
\hline & & $\begin{array}{l}\text { Pencahayaan } \\
\text { Akustik }\end{array}$ \\
\hline \multirow{3}{*}{ Teknikal } & Instalasi & $\begin{array}{l}\text { Kesesuaian } \\
\text { (compatibility) })\end{array}$ \\
\cline { 2 - 3 } & Operasional & $\begin{array}{l}\text { Efisiensi } \\
\text { Daya Tahan } \\
\text { Fleksibilitas }\end{array}$ \\
\hline \multirow{5}{*}{ Ekonomi } & Biaya & $\begin{array}{l}\text { Biaya modal } \\
\text { Biaya energi } \\
\text { operasional } \\
\text { Biaya perawatan dan } \\
\text { penggantian }\end{array}$ \\
\hline & & Sumber: Si et al., 2016
\end{tabular}

\subsubsection{Lingkungan}

Dampak retrofit pada konsumsi energi seluruh bangunan biasanya diukur dalam hal penghematan energi tahunan dibandingkan dengan konsumsi energi sebelumnya. Retrofit bangunan bertujuan untuk mengurangi konsumsi energi operasional dan embodied energy. Energi yang terkandung (embodied energy) sekitar 1/3 dari keseluruhan konsumsi energi bangunan untuk ekstraksi, pemrosesan, transportasi, dan pemasangan bahan bangunan (Nag, 2019). Energi operasional diperlukan untuk layanan bangunan, seperti HVAC, penerangan, dan fasilitas lainnya. Namun, dalam mengurangi energi operasional, dapat dilihat dari selubung bangunan, wall insulation, langit-langit bangunan, lantai, dan penempatan jendela yang efektif untuk ventilasi serta pencahayaan alami yang lebih banyak. Selain itu pemanfaatan energi terbarukan untuk pemenuhan kebutuhan operasional bangunan akan membantu pengurangan dampak lingkungan.

\subsubsection{Sosial}

Efek dari kualitas lingkungan dalam ruangan pada penghuni bangunan diukur oleh empat faktor, diantaranya; kenyamanan termal, kualitas udara dalam ruangan, pencahayaan, dan akustik (Nag, 2019). Hal ini erat kaitannya dengan kepuasan penghuni terhadap lingkungan dalam ruang bangunan. Beberapa bagian bangunan yang mempengaruhi kualitas lingkungan dalam ruang diantaranya material, pelapis interior, dan produk pembersih atau pemeliharaan ruang. Pemilihan bahan serta produk dengan emisi VOC nol atau rendah, merancang sistem ventilasi yang memungkinkan masuknya udara bersih dari luar dapat meningkatkan kualitas lingkungan dalam bangunan. Secara singkat, interaksi di antara semua komponen dalam ruangan, termasuk penghuni bangunan, menentukan IEQ (WBDG 2009). Meningkatkan IEQ (indoor environmental quality) memiliki pengaruh langsung terhadap produktivitas pekerja dan pembayaran biaya (Boué 2013).

\subsubsection{Teknikal}

Retrofit pada bangunan eksisting dilakukan untuk menurunkan biaya operasional, meningkatkan kualitas lingkungan dalam ruangan, dan kesejahteraan penghuninya. Ada beberapa peluang dalam meningkatkan kinerja energi bangunan (building energy performance), termasuk selubung bangunan, layanan bangunan seperti pendinginan, ventilasi, penerangan, sistem transportasi, dan peralatan di dalam gedung (Kontokosta, 2016). Langkah atau peluang dalam penghematan energi (energy conservation measurement) tergantung pada kondisi bangunan yang ada. Pada dasarnya, inovasi dalam retrofit adalah tentang perubahan bangunan menuju keberlanjutan (Swan and Brown, 2013). Terdapat beberapa jenis produk fisik yang dapat diterapkan pada properti untuk meningkatkan kinerja energinya yang dijelaskan pada gambar 4.

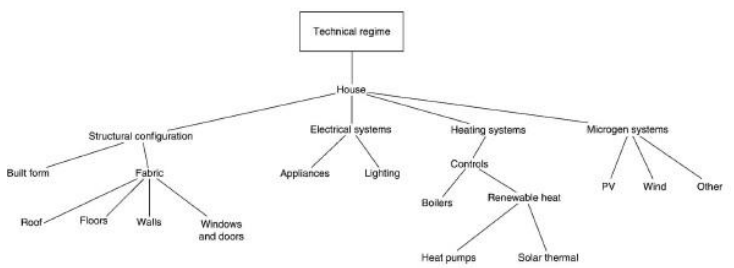

Gambar 4. Hierarki Retrofit Produk oleh Geels, 2005

Sumber: Swan and Brown, 2013

\subsubsection{Ekonomi}

Biaya yang dikeluarkan untuk melakukan retrofit bangunan mencakup biaya investasi (modal), operasional, pemeliharaan, dan penggantian (Kontokosta, 2016). Investasi efisiensi energi dalam bangunan komersial biasanya meliputi penerangan, pemanasan, ventilasi atau pendinginan berupa $\mathrm{AC}$ (HVAC) serta motor/mesin, atap reflektif dan berbagai aplikasi lainnya. Pilihan efisiensi dibuat selama desain awal retrofit bangunan, ketika peralatan aus dan diganti, atau selama peningkatan efisiensi yang dapat terjadi kapan saja. Dasar 
analisis investasi yakni dengan keputusan investasi penganggaran modal (capital budgeting). Keputusan investasi penganggaran modal tradisional mengidentifikasi investasi efisiensi energi yang menguntungkan ketika discounted sum of savings $(\mathrm{S})$, lebih besar dari biaya investasi (I). Net present value (NPV) memberikan perkiraan manfaat finansial bersih yang diberikan kepada perusahaan jika investasi ini dilakukan (Vincenzo Corrado, 2018).

Metode ini ditujukan untuk menghitung indikator ekonomi, seperti net present value (NPV), internal rate of return (IRR), payback period (PP), benefit cost ratio (BCR), dan profitability index (PI). Mempertimbangkan berbagai opsi retrofit bangunan, metode NPV digunakan untuk menentukan dan membandingkan efektivitas biaya dari opsi yang diusulkan. Dalam analisis arus kas (cash flow analysis), pendapatan tahunan dianggap sebagai biaya tahunan yang dihindari, ditentukan sebagai perbedaan antara biaya tahunan bangunan sebelum dan sesudah retrofit. Biaya tahunan umumnya mengacu pada operasional bangunan dan aspek lainnya, seperti pemeliharaan gedung, penggantian komponen, dll. Opsi retrofit yang memiliki nilai NPV positif berbiaya efektif, karena jumlah pendapatan yang diaktualisasikan lebih tinggi dari jumlah biaya yang diaktualisasikan (termasuk biaya investasi pada t0) selama periode penilaian (Krarti, 2018). Opsi retrofit terbaik pada dasarnya adalah yang memiliki NPV tertinggi. Jika PP juga dipertimbangkan, pilihan terbaik dicirikan oleh NPV tertinggi dan PP terendah.

\subsection{Strategi Retrofit Bangunan}

Strategi bangunan hemat energi dikaitkan dalam tiga aspek yakni; energi \& lingkungan, kualitas air \& konservasi, serta sumber daya alam \& material bangunan (Nag, 2019). Dimana masing-masing aspek berhubungan dengan arsitektur atau strategi pasif, terkait dengan desain bangunan, instalasi mekanik dan pertimbangan distribusi layanan energi, serta pembangkit energi yang menggunakan sumber daya terbarukan. Beberapa strategi maupun teknologi yang dapat diterapkan pada bangunan hemat energi diantaranya (Nag, 2019):

1. Energi dan Lingkungan (Energy and Environment) a. Orientasi bangunan dan posisi jendela.

b. Penggunaan window shading.

c. Memaksimalkan daylighting.

d. Pemasangan daylight controls.

e. Menggunakan lampu hemat energi dan sensor penerangan.

f. Penggunaan peralatan kantor yang efisien terhadap penggunaan energi.

g. Memanfaatkan energi terbarukan.

h. Menggunakan high performance windows.

i. Penggunaan sistem pendinginan udara dan pump motors yang efisien.

2. Kualitas Konservasi dan Air (Water Quality and Conservation)

a. Menentukan tapak bangunan.

b. Minimalkan penggalian dan pemadatan lapisan tanah yang ada.

c. Menggunakan teknologi air hujan yang memiliki dampak rendah.

d. Harvest, process dan recycle rainwater.

e. Memertahankan kualitas air tanah.

f. Menggunakan water fixtures yang efisien.

3. Material dan Sumber Daya (Materials and Resources)

a. Meminimalkan penggunaan sumber daya dan material yang tidak terbarukan.

b. Maksimalkan penggunaan bahan daur ulang.

c. Membuat rencana manajemen pengurangan limbah.

d. Menerapkan program daur ulang limbah.

e. Menggunakan bahan-bahan yang diproduksi secara lokal.

f. Menggunakan lumbar dan produk kayu dari hutan bersertifikat.

\subsection{Metode Penilaian Retrofit}

Berbagai metode penilaian dapat digunakan untuk memperkirakan atau mengukur kinerja retrofit ke bangunan yang ada. Salah satu metode yang akan dibahas yakni building energy simulation (BES) atau pemodelan energi. Metode ini paling sering dilakukan karena dapat memprediksi kondisi bangunan di masa depan. Setiap data mengenai kondisi bangunan yang ada saat ini menjadi dasar dari data baseline. Dalam konteks retrofit, BES digunakan untuk mensimulasikan kondisi bangunan saat ini, yang berfungsi sebagai dasar untuk perbandingan terhadap satu atau lebih 
solusi retrofit yang disimulasikan. BES adalah alat yang banyak digunakan dan memiliki kapasitas untuk mengevaluasi penghematan energi dari berbagai tindakan retrofit yang dipilih. Program sertifikasi bangunan bernama EDGE yang bekerjasama dengan pemerintah Indonesia juga meluncurkan aplikasi permodelan bangunan dimana pengguna dapat melakukan analisis retrofit secara mandiri.

EDGE merupakan salah satu aplikasi simulation modelling yang memberdayakan penemuan solusi teknis pada tahap desain awal untuk mengurangi biaya operasional dan dampak lingkungan. Berdasarkan input informasi pengguna dan pemilihan tindakan hijau (opsi retrofit), EDGE mengungkapkan proyeksi penghematan operasional dan pengurangan emisi karbon. Gambaran keseluruhan kinerja ini membantu untuk mengartikulasikan studi kasus untuk bangunan hijau. Program EDGE memiliki data base biaya yang dapat digunakan untuk membantu dalam menghitung biaya modal dan dampak dari keputusan desain. Perangkat lunak EDGE menyediakan modal komparatif dan biaya utilitas dampak dari keputusan. Hal ini dilakukan untuk mengoptimalkan kinerja fasilitas terhadap kebutuhan pengguna, serta pengembalian investasi atau 'nilai untuk uang'. Kemudahan dan kelengkapan data menjadi dasar pemilihan EDGE sebagai perangkat lunak yang digunakan dalam menganalisis. Berikut ini beberapa tahapan yang dilakukan pada program EDGE (International Finance Corporation, 2018):

\section{Pengisian Data}

Data yang dibutuhkan terkait dengan kondisi eksisting bangunan seperti detail bangunan, lokasi, data utilitas bangunan berkaitan dengan penggunaan energi, orientasi dan sistem bangunan.

2. Opsi Retrofit

Opsi retrofit energi dipilih berdasarkan hasil dari analisa harapan pembuat keputusan. Tidak perlu untuk mengevaluasi semua faktor kinerja bangunan hemat energi untuk setiap proyek retrofit energi, hanya untuk opsi retrofit yang dipilih, tipe properti, dan tipe kepemilikan yang diperlukan. Pada bangunan eksisting faktor konvensional (lokasi, akses, usia, dll) tidak berubah setelah adanya penerapan retrofit energi.

\section{Analisis Finansial}

Fitur efisiensi energi dapat berkontribusi pada lebih dari satu indikator kinerja yang dapat memainkan peran dalam kinerja keuangan subjek properti yang ada atau opsi yang dipilih. Analisis finansial dimulai dari penilaian komprehensif terhadap langkahlangkah efisiensi energi dan indikator kinerja bangunan. Dimana hal ini akan memberikan dasar dalam menilai kinerja pembangunan yang dapat berdampak secara langsung terhadap input nilai keuangan. Program EDGE akan melaporkan beberapa data finansial dari retrofit bangunan diantaranya biaya utilitas, biaya penghematan, biaya investasi dan periode pengembalian.

\subsection{Proses Pemilihan Retrofit}

Manfaat yang diharapkan serta hambatan yang dirasakan dari tindakan retrofit dipengaruhi oleh keputusan pemilik atau stakeholder bangunan komersial terkait. Setiap langkah konservasi energi didorong oleh serangkaian faktor endogen dan eksogen. Hal ini termasuk pada konteks peraturan, risiko, kelangsungan bisnis, pengetahuan dan kesadaran, serta permintaan penghuni (Kontokosta, 2016). Hubungan dan interaksi faktor-faktor ini ditunjukkan pada Gambar 5. Dimana setiap faktor akan berdampak pada keputusan retrofit melalui pertimbangan ekonomi / keuangan dan kelayakan teknis, yang berpotensi dimediasi oleh pengaruh sosial.

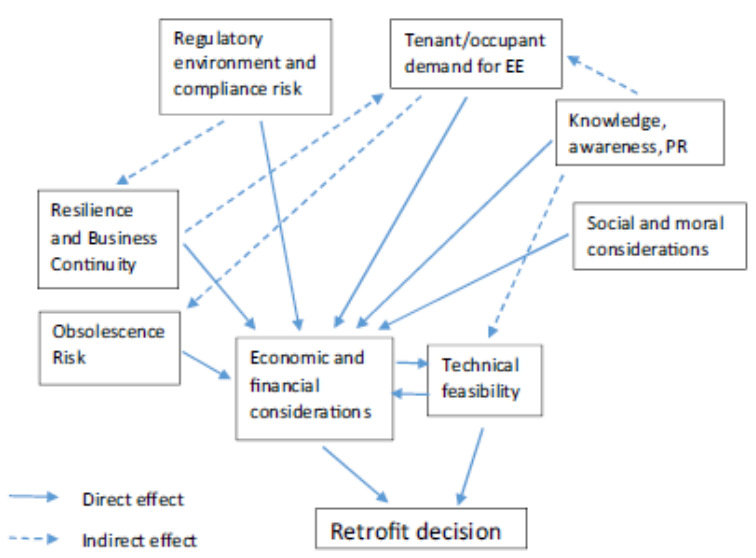

Gambar 5. Faktor yang Mempengaruhi Keputusan Retrofit.

Sumber: Kontokosta, 2016 


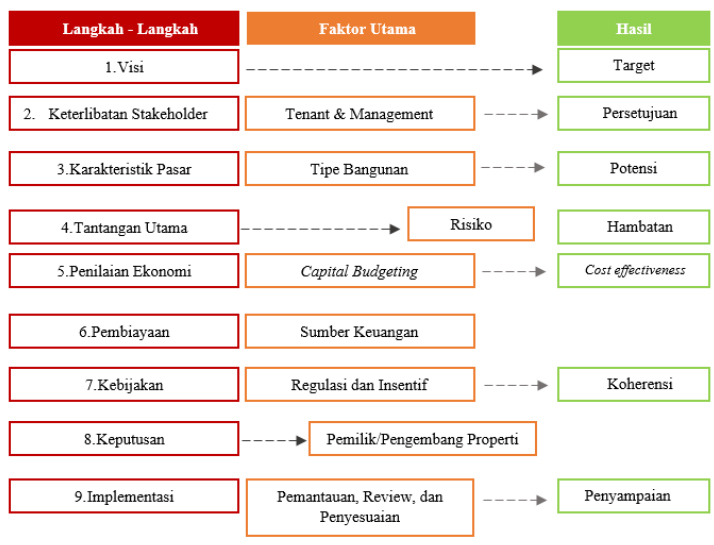

Gambar 6. Langkah Menuju Retrofit Bangunan. Sumber:Penulis, 2020

Pendekatan yang dilakukan untuk pengembangan strategi retrofit berkaitan dengan sembilan aspek, yaitu (Gambar 6):

1. Visi: penetapan visi strategi jangka panjang, dan target terkait keberlanjutan bangunan.

2. Keterlibatan stakeholder: keterlibatan pemangku kepentingan, pemahaman, keberpihakan dan komitmen baik dari manajemen dan tenant sebagai penghuni bangunan.

3. Karakteristik pasar: pengelompokan, pembuatan profil, serta upaya untuk memahami pasar bangunan yang ada. Pemilik/investor mengidentifikasi potensi peningkatan kinerja energi dikaitkan dengan pasar properti.

4. Hambatan dan tantangan utama: pertimbangan dalam menilai dan mengatasi tantangan dan hambatan utama untuk melakukan retrofit.

5. Penilaian ekonomi: menilai biaya teknis, ekonomi dan manfaat dari renovasi energi bangunan, dari investor dan perspektif tenant.

6. Pembiayaan: mengukur, mencari, merancang dan memberikan keuangan yang diperlukan, dan dalam mengelola risiko terkait renovasi yang akan dilakukan.

7. Kebijakan: menilai opsi dan merumuskan kebijakan untuk merangsang, mengoordinasikan, dan mengatur kegiatan renovasi kualitas dalam skala besar.

8. Keputusan: pertimbangan terkait tindakan retrofit untuk menciptakan kepercayaan investor.
9. Implementasi: pertimbangan terkait dengan pemasangan fitur atau teknologi baru pada bangunan yang sudah terbangun dalam jangka pendek dan pada visi jangka panjang.

Penelitian Bozorgi (2015) memperkenalkan tentang analisis keputusan investasi yang menggabungkan metode keuangan, resiko dan ketidakpastian. Pada penelitian tersebut Bozorgi (2015) mengusulkan pendekatan penilaian baru untuk memperkirakan nilai sebenarnya dari bangunan berkelanjutan, dengan pendekatan baru ini, desainer juga dapat lebih memahami dampak keputusan desain terhadap kinerja keuangan bangunan berkelanjutan pada tahap desain atau usulan perbaikan yang akan menghasilkan desain yang lebih layak (Gambar 7). Dalam pengembangan proses pertimbangan utama adalah manfaat lingkungan, sosial, dan ekonomi dalam konteks nilai.

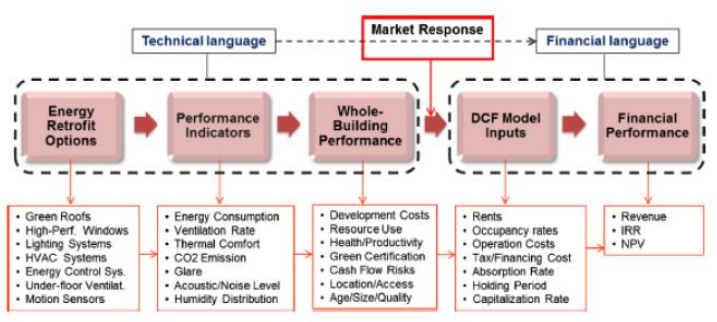

Gambar 7. Proses penilaian berbasis nilai untuk menurunkan kinerja keuangan dari opsi retrofit energi.

Sumber: Bozorgi, 2015

Proses pertama dimulai dengan memilih fitur yang berkelanjutan dan memperkirakan indikator kinerja bangunan terkait melalui building simulation program (BPS) yang sesuai. Untuk setiap sistem yang dipilih, indikator kinerja bangunan tertentu dapat ditentukan, misalnya, konsumsi energi sebagai indikator kinerja energi, atau tingkat ventilasi dan polusi sebagai indikator untuk kualitas udara dalam ruangan. Kemudian, tergantung pada sistem dan indikator kinerjanya, sistem yang dipilih akan dimodelkan melalui BPS yang sesuai. Mungkin perlu untuk memodelkan fitur berkelanjutan tertentu dengan beberapa BPS karena sebagian besar fitur berkelanjutan memiliki dampak lebih dari satu indikator pada kinerja bangunan yang secara langsung atau tidak langsung berkontribusi pada nilai bangunan. Misalnya penggunaan HVAC yang 
efisien dalam penggunaan energinya sehingga dapat mengurangi biaya operasional tetapi pada saat yang sama dapat meningkatkan kualitas udara dalam ruangan yang dapat meningkatkan kesehatan dan produktivitas. Sangat penting bagi desainer untuk menyadari bahwa indikator kinerja bangunan dapat memengaruhi kinerja keuangan suatu bangunan. Sehingga diperlukan evaluasi menyeluruh dari semua indikator kinerja yang mungkin dipengaruhi oleh fitur berkelanjutan.

Kedua adalah menentukan kinerja bangunan baik dari segi faktor berkelanjutan dan nonberkelanjutan. Faktor-faktor yang terkait dengan fitur berkelanjutan termasuk biaya pengembangan, kepuasan penghuni, dan kesehatan dan produktivitas, sertifikasi berkelanjutan berkontribusi dalam insentif yang dapat dicapai, pasar, risiko, dll. Kinerja bangunan yang tidak berkelanjutan, yang tidak terkait dengan fitur berkelanjutan tetapi penting dalam penilaian properti adalah lokasi, akses, umur, ukuran, dll. Ketika mengevaluasi bangunan berkelanjutan, beberapa faktor berkelanjutan seperti biaya, kemungkinan untuk mencapai sertifikasi atau insentif, dapat diperkirakan secara relatif mudah berdasarkan data yang tersedia, pedoman, peraturan dan hasil BPS. Namun, faktor-faktor seperti kepuasan pengguna, serta kesehatan dan produktivitas lebih sulit diukur secara tepat.

Ketiga adalah memilih input model keuangan utama berdasarkan estimasi kinerja bangunan, yang mencakup semua biaya, manfaat, dan risiko yang terkait dengan investasi pembangunan berkelanjutan. Pendekatan discounted cash flow (DCF) tradisional disarankan sebagai model dasar untuk memperkirakan nilai sebenarnya dari bangunan berkelanjutan. Penilai mempertimbangkan semua faktor yang berkelanjutan dan tidak berkelanjutan, ditentukan dalam langkahlangkah sebelumnya, secara bersamaan, menilai respons pasar (regulasi, pengguna ruang dan permintaan Pengembang) dan memperkirakan input model DCF. Terakhir adalah menghitung nilai berdasarkan input model DCF. Simulasi Monte Carlo dengan kasus dasar yang dibangun berdasarkan pendekatan DCF disarankan untuk memperkirakan indikator kinerja keuangan akhir saat memodelkan ketidakpastian.

\subsection{Manfaat Retrofit Bangunan}

Tujuan dari retrofit bangunan adalah keberlanjutan sehingga mengurangi beban energy dan dampak lingkungan. Menurut Abdul Qayyum et al., pada tulisan Khairi, Jaapar and Yahya, (2017) salah satu keuntungan dari melakukan retrofit pada bangunan yang sudah berdiri dibandingkan dengan membangun bangunan hijau baru adalah produksi limbah terkait dapat dicegah sambil melestarikan energi yang terkandung. Retrofit juga merupakan cara yang hemat biaya untuk menghijaukan bangunan yang ada dengan mengurangi konsumsi energi, biaya operasional dan biaya siklus hidup bangunan sehingga menciptakan pengembalian investasi yang lebih tinggi kepada klien. Selain itu, retrofit dapat memberikan kualitas lingkungan dalam ruangan yang lebih baik bagi pengguna. Efisiensi energi yang diterapkan dalam bangunan sebagai salah satu manfaat dari segi lingkungan dan ekonomi. Dari sektor lingkungan emisi karbon yang dihasilkan menjadi berkurang, sedangkan dari sisi ekonomi adanya peningkatan nilai dari bangunan yang sudah di retrofit.

\section{KESIMPULAN}

Artikel ini telah mengkaji perkembangan penelitian mengenai retrofit energi pada bangunan komersial. Permasalahan utama yang menjadi dasar penulisan mengenai manfaat, kriteria, metode, serta proses yang digunakan untuk menilai dampak retrofit dan memilih retrofit yang sesuai. Retrofit bangunan digambarkan sebagai tindakan yang menyeimbangkan berbagai kriteria. Terdapat empat kriteria utama yang berkaitan dengan retrofit bangunan diantaranya lingkungan, sosial, teknikal, dan ekonomi. Beberapa strategi retrofit yang dapat dilakukan berkaitan dengan elemen bangunan diantaranya energi dan konservasi serta sumber daya dan material bangunan. Setiap strategi ditentukan berdasarkan kondisi bangunan dan kebutuhan. Saat ini sudah banyak perangkat lunak yang mengembangkan analisa simulasi kinerja bangunan. Salah satu aplikasi yang dibahas dalam artikel ini adalah EDGE. Dimana aplikasi ini sangat mudah digunakan dan terintegrasi dengan layanan sertifikasi 
bangunan hijau. Untuk melakukan analisis dengan EDGE terdapat beberapa data yang diperlukan seperti detail proyek, data bangunan, konsumsi energi selama satu tahun terakhir dan sistem bangunan. EDGE akan menggambarkan kinerja bangunan yang disimulasikan dan aktual. Dalam proses pemilihan opsi retrofit ada beberapa faktor yang mempengaruhi keputusan dari retrofit yakni peraturan, risiko, keberlangsungan bisnis, pengetahuan dan kesadaran, serta permintaan penghuni atau tenant. Dimana tiap faktor akan berdampak pada keputusan investasi melalui pertimbangan ekonomi atau keuangan dan kelayakan teknis. Disisi lain manfaat yang didapatkan dari retrofit bangunan antara lain; penghematan biaya, baik dari segi operasional maupun siklus hidup bangunan, peningkatan kualitas lingkungan dalam ruangan yang lebih baik bagi pengguna, dan peningkatan nilai ekonomi bangunan. Retrofit untuk bangunan komersial, apabila diterapkan dengan hati-hati, tidak hanya memberikan kesempatan untuk mengurangi konsumsi energi dan emisi karbon, tetapi juga dapat berfungsi sebagai alat untuk membantu melestarikan bangunan untuk generasi mendatang.

\section{REFERENSI}

Bozorgi, A. (2015) 'Integrating value and uncertainty in the energy retrofit analysis in real estate investment - next generation of energy efficiency assessment tools', Energy Efficiency, 8(5), pp.

Gunawan, B. dkk (2012) Buku Pedoman Energi Efisiensi untuk Desain Bangunan Gedung di Indonesia-Pengembang dan Pemilik Bangunan. 1st edn. Jakarta: Energy Efficiency and Conservation Clearing House Indonesia.

Hong, Y., Deng, W. and Ezeh, C. I. (2019) 'Low-rise Office Retrofit: Prerequisite for Sustainable and Green Buildings in Shanghai', IOP Conference Series: Earth and Environmental Science, 281(1).

International Finance Corporation (2017) Green Buildings Market Intelligence Indonesia Profile.

International Finance Corporation (2018) Edge User Guide. International Finance Corporation.
Khairi, M., Jaapar, A. and Yahya, Z. (2017) 'The application, benefits and challenges of retrofitting the existing buildings', IOP Conference Series: Materials Science and Engineering, 271(1).

Kontokosta, C. E. (2016) 'Modeling the energy retrofit decision in commercial office buildings', Energy and Buildings. Elsevier B.V., 131, pp. 1-20.

Krarti, M. (2018) 'Life-Cycle Cost and Energy Productivity Analyses', in Optimal Design and Retrofit of Energy Efficient Buildings, Communities, and Urban Centers. Elsevier Inc.

Ma, Z. et al. (2012) 'Existing building retrofits: Methodology and state-of-the-art', Energy and Buildings. Elsevier B.V., 55, pp. 889902.

Mendes, E. and Mendes, N. (2019) 'An instructional design for building energy simulation e-learning: an interdisciplinary approach', Journal of Building Performance Simulation. Taylor \& Francis, pp. 1-17.

Morrissey, J., Dunphy, N. and MacSweeney, R. (2014) 'Energy efficiency in commercial buildings: Capturing added-value of retrofit', Journal of Property Investment and Finance, 32(4), pp. 396-414.

Nag, P. K. (2019) Office Buildings. 1st edn, Design Science and Innovation. 1st edn. Edited by A. Chakrabarti. springer singapore.

Si, J. et al. (2016) 'Assessment of buildingintegrated green technologies: A review and case study on applications of Multi-Criteria Decision Making (MCDM) method', Sustainable Cities and Society. Elsevier B.V., 27, pp. 106-115.

Si, J. and Marjanovic-Halburd, L. (2018) 'Criteria weighting for green technology selection as part of retrofit decision making process for existing non-domestic buildings', Sustainable Cities and Society. Elsevier, 41(June), pp. 625-638.

Snyder, H. (2019) 'Literature review as a research methodology: An overview and guidelines', Journal of Business Research. Elsevier, 104(July), pp. 333-339.

Swan, W. and Brown, P. (2013) Retrofitting The Built Environment. 1st edn, Retrofitting the City. 1st edn. Edited by W. Swan and P. Brown. Wiley. 
Vincenzo Corrado, I. B. and F. F. (2018) 'Energy Efficiency in Building Renovation', in Asdrubali, F. and Desideri, U. (eds) Handbook of Energy Efficiency in Buildings. 1st edn. Matthew Deans, pp. 675-810.

Woo, Y. E. and Cho, G. H. (2018) 'Impact of the surrounding built environment on energy consumption in mixed-use building, Sustainability (Switzerland), 10(3). 


\section{LAMPIRAN}

Gambar 1. Pertumbuhan Stok Bangunan di Indonesia

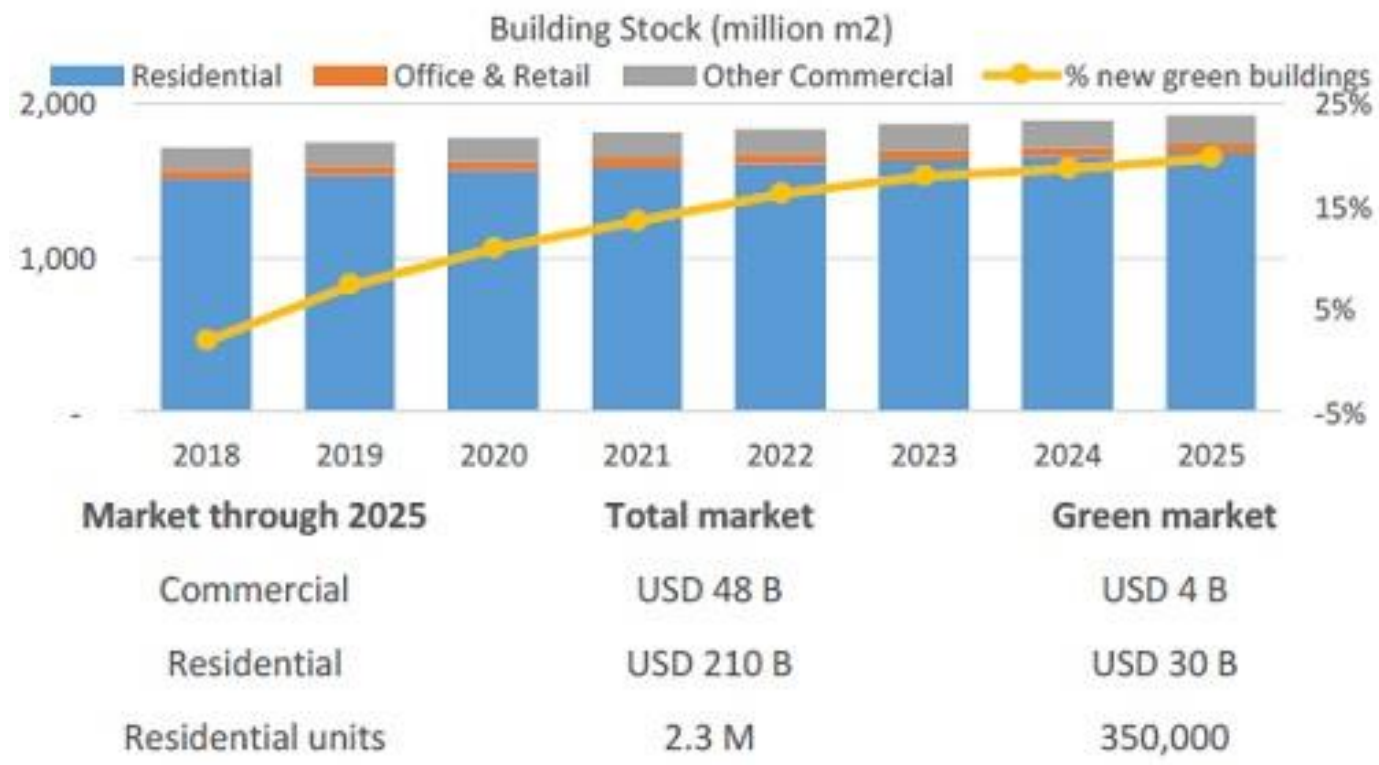

Sumber: Na vigant Research Global Building Stock Da tabase, 2017

Gambar 2. Pertumbuhan Pasar Properti Indonesia

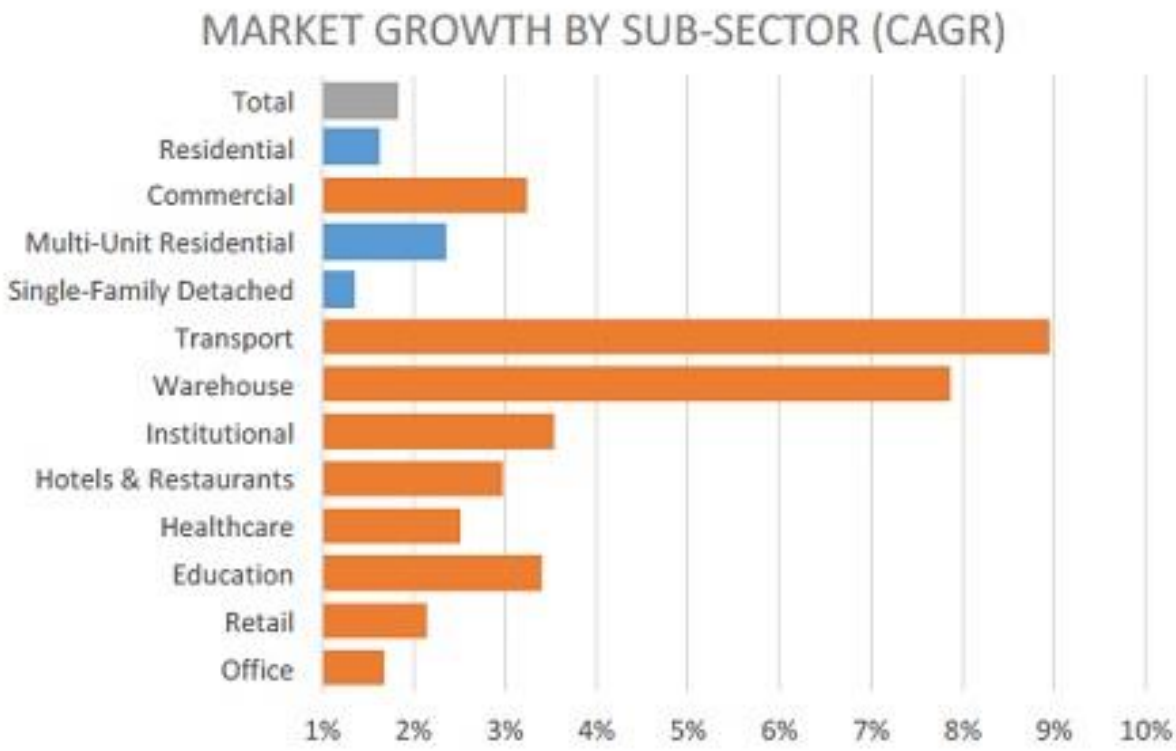

Sumber: Na viga nt Research Global Building Stock Da tabase, 2017. 
Gambar 3. Tiga tingkatan sistem sosial-teknis yang diadaptasi teori Geels 2005

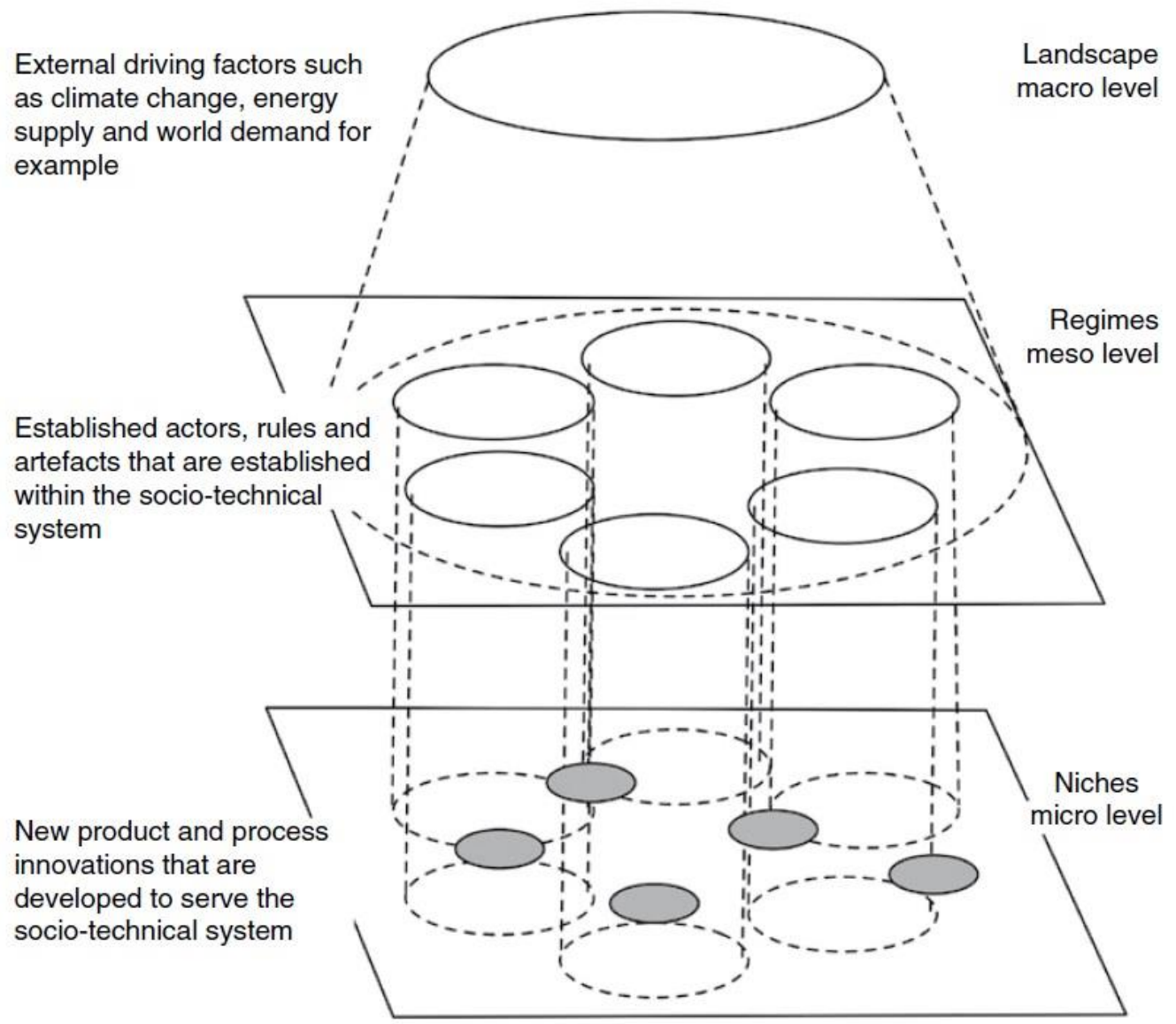

Sumber: Swa nand Brown, 2013 
Gambar 4. Hierarki Retrofit Produk oleh Geels, 2005

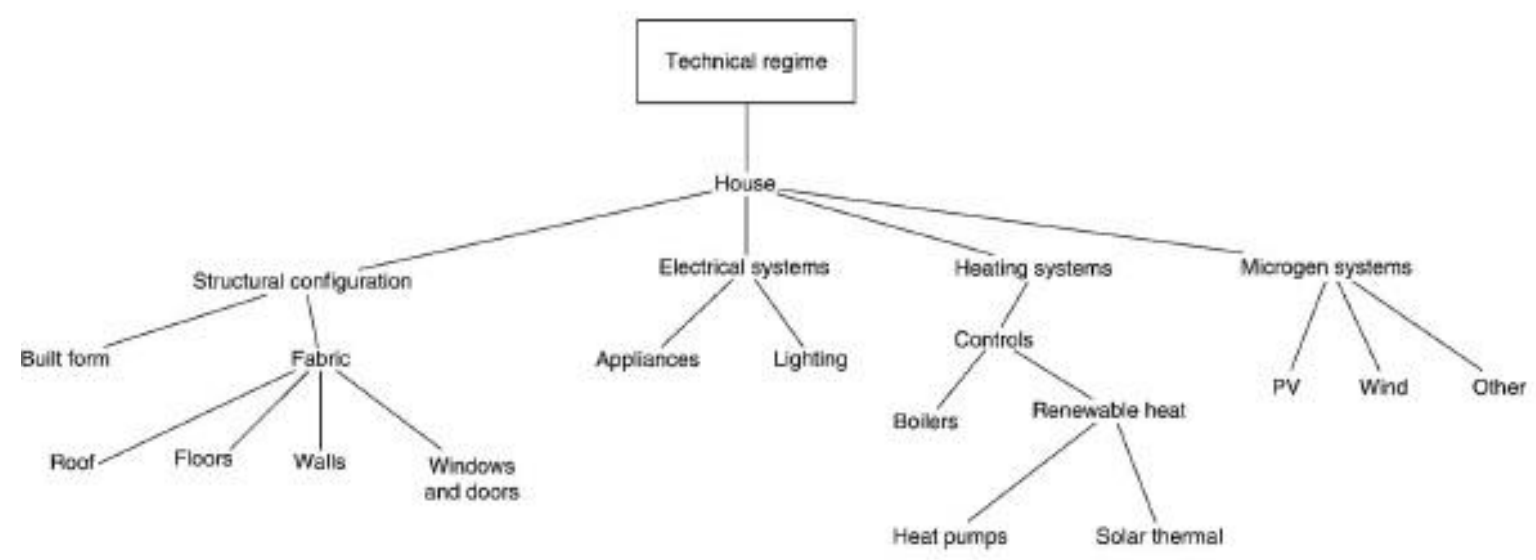

Sumber: Swan and Brown, 2013

Gambar 5. Faktor yang Mempengaruhi Keputusan Retrofit.

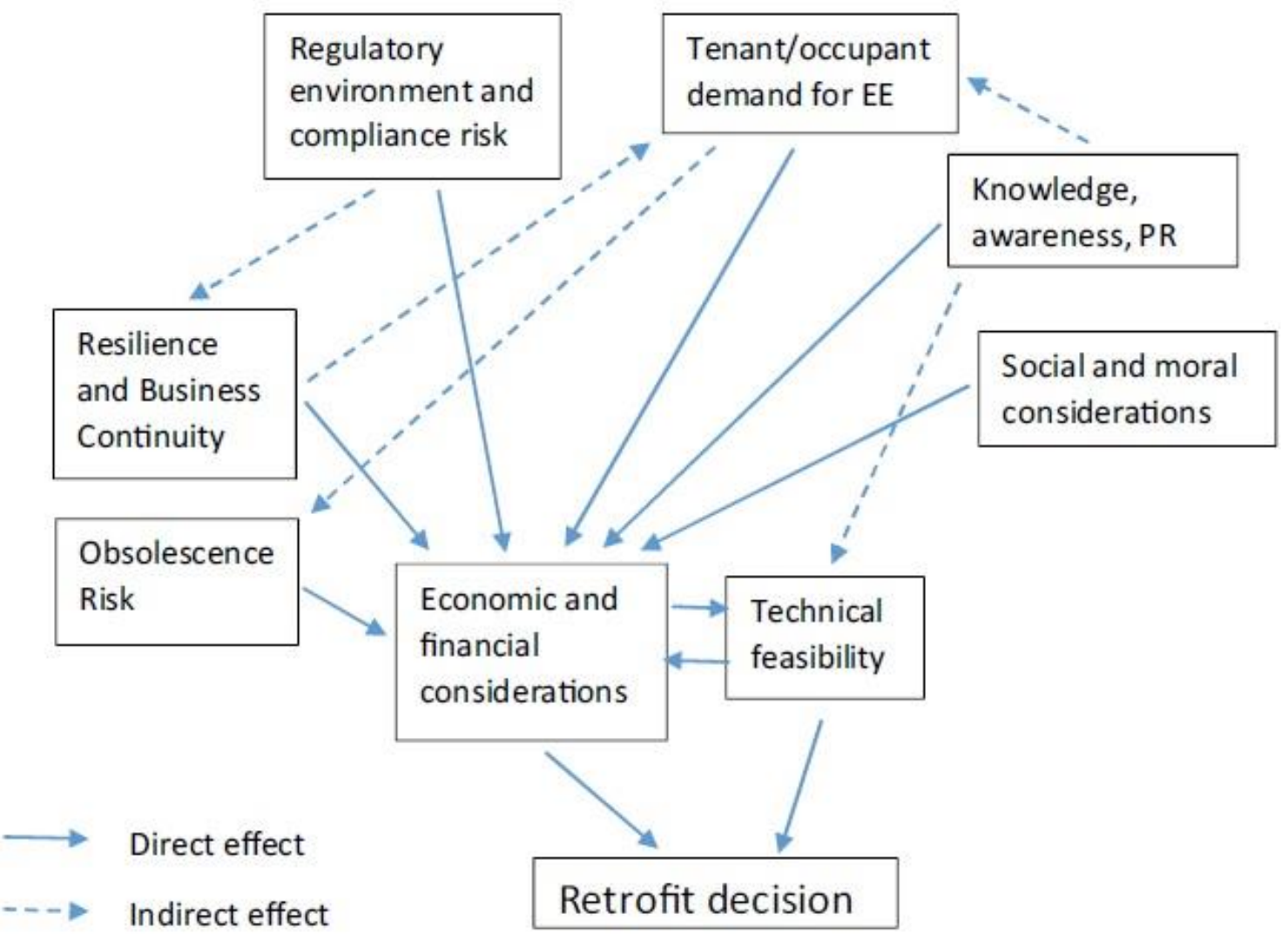

Sumber: Kontokosta, 2016 
Gambar 6. Langkah Menuju Retrofit Bangunan.

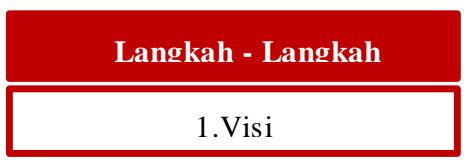

Faktor Utama

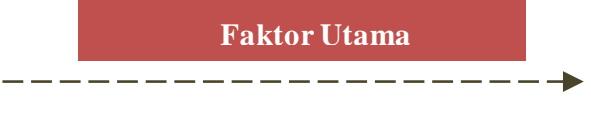

2. Keterlibatan Stakeholder

Tenant \& Management
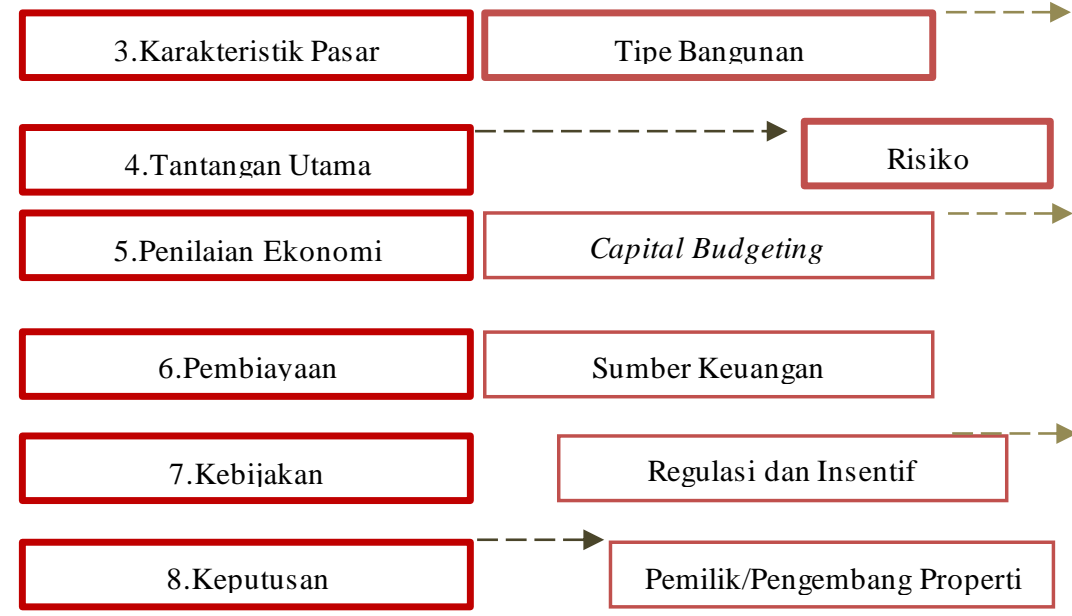

Sumber Keuangan

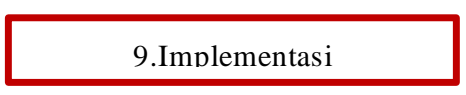

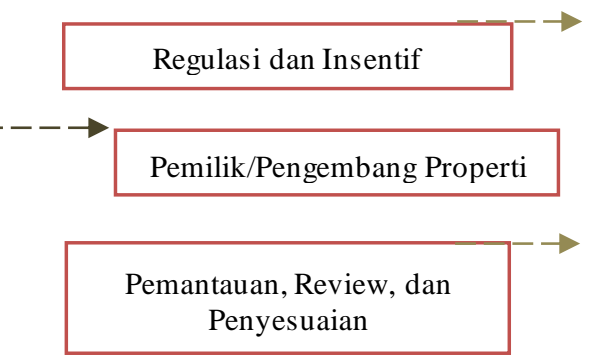

Sumber: Penulis, 2020

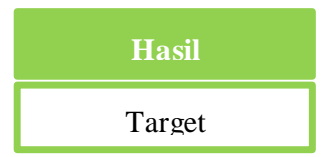

Persetujuan

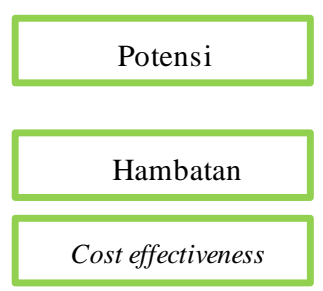

Koherensi

Penyampaian 
Gambar 7. Proses penilaian berbasis nilai untuk menurunkan kinerja keuangan dari opsi retrofit energi.

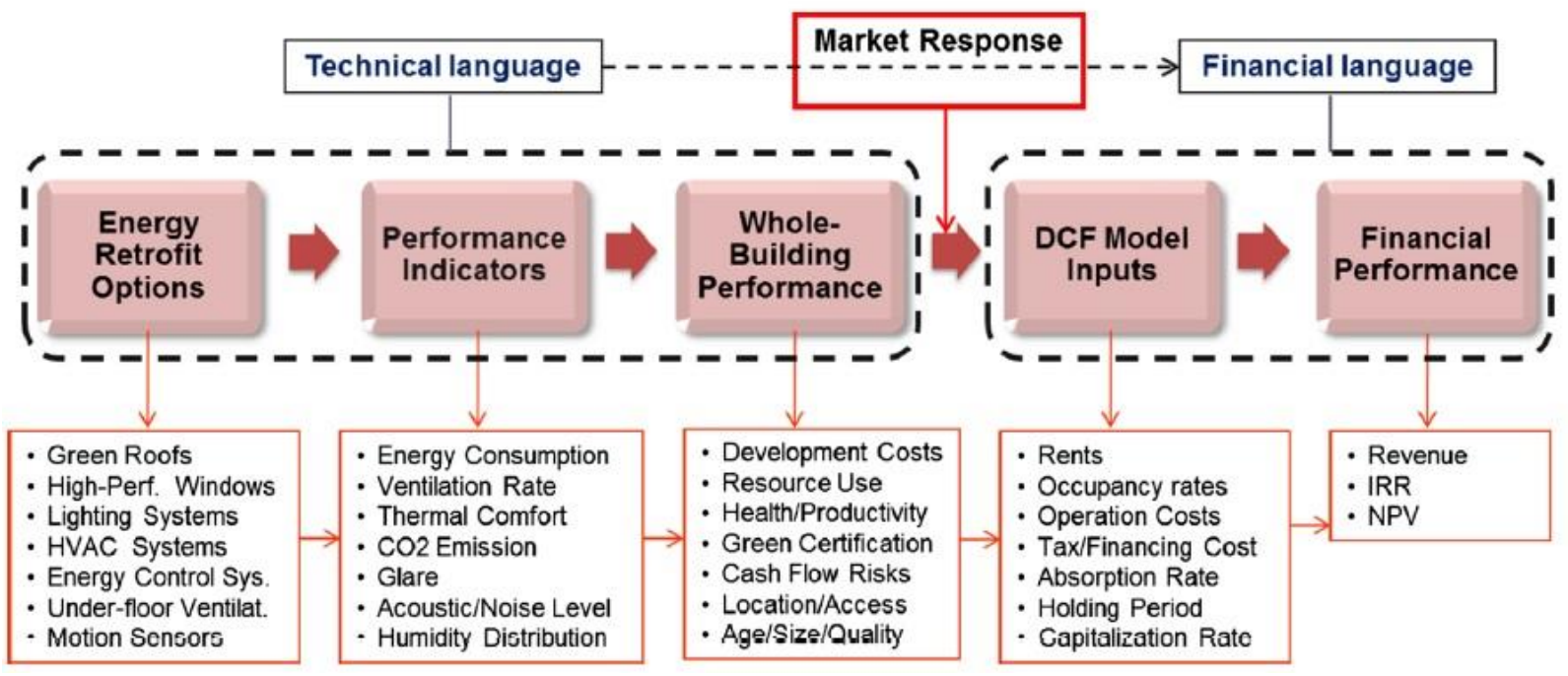

Sumber: Bozorgi, 2015 